\title{
SFM PHOTOGRAMMETRY AS A TOOL FOR THE CONSERVATION OF THE CULTURAL HERITAGE OF BOGOTÁ (COLOMBIA), WITHIN THE FRAMEWORK OF THE ADOPT A MONUMENT PROGRAM
}

\author{
L. D. Tavera ${ }^{1 *}$, A. Páez ${ }^{2}$, L.A. Rocha ${ }^{3}$, L.A. Dallos ${ }^{1}$, J. D. Gonzales ${ }^{2}$, E. Upegui ${ }^{4}$ \\ ${ }^{1}$ Cadastral and Geodesy Engineering, hotbed of research SDI (Infraestructura de Datos Espaciales) Space Data Infrastructure, \\ Universidad Distrital Francisco José de Caldas, Bogotá, Colombia - (ldtaverac, ladallosp) @ correo.udistrital.edu.co \\ ${ }^{2}$ Cadastral and Geodesy Engineering, hotbed of research GRSS-IEEE UD, Universidad Distrital Francisco José de Caldas, Bogotá, \\ Colombia - (ampaezc, jdgonzalezh) @ correo.udistrital.edu.co \\ ${ }^{3}$ Universidad Distrital Francisco José de Caldas, Bogotá, Colombia, Director research Group NIDE and hotbed of research SDI \\ (Infraestructura de Datos Espaciales) Space Data Infrastructure. lrocha@udistrital.edu.co \\ ${ }^{4}$ Universidad Distrital Francisco José de Caldas, Faculty of Engineering, GEFEM and GRSS-IEEE UD Groups, Bogotá, Colombia - \\ esupeguic@udistrital.edu.co
}

\section{Commission II}

KEY WORDS: SFM Photogrammetry, Colombia Cultural Heritage, La Rebeca, San Agustín No. 28, 3D Reconstruction, Pix4d, Conservation.

\begin{abstract}
:
As stated by the UNESCO, cultural heritage is both a product and a process that provides societies with a wealth of resources that are inherited from the past, they are currently created present and transmitted to future generations for their benefit. According to its needs each country has regulated and taken actions aimed at preserving its heritage (UNESCO,2017). In the case of the city of Bogotá, different regulations have been enacted seeking to protect and preserve the cultural heritage. Recently, the Instituto Distrital de Patrimonio Cultural (IDPC) (District Institute of Cultural Heritage), with the Secretaria de Planeación Distrital and the Instituto de Desarrollo Urbano, began developing work of an inventory and valuation of the sculptures and monuments found in the public space of Bogotá. In this context, this project seeks to contribute, from the academy, in the virtualization of the cultural heritage of the city by using the Photogrammetry SfM. For this purpose, two emblematic monuments of the city have been selected in order to reconstruct them three-dimensionally and therefore contribute to their conservation as a heritage. The chosen monuments correspond to a replica of the sculpture of San Agustín No. 28 which represents the God of War of that culture and the Rebeca, first nude located in public place in Bogota. Several images were taken from each monument, using different device and software's. The product obtained meets the initial expectation of three-dimensional reconstruction and establishes a workflow to be applied to other monuments in the city or anywhere.
\end{abstract}

\section{INTRODUCTION}

Today, the preservation of history through the preservation of cultural heritage has marked a milestone, that is why efforts have been made to generate new techniques and methods that allow to have a record of the heritage with low-cost techniques. That's where 3D modeling has become an important tool for cultural heritage virtualization, in many cities has been used in order to document the culturally interesting assets that I know it has, making use of new technologies. (Caro,2012).

Caro (2012) notes that photogrammetry is a technique that allows to generate 3D models with two advantages: The first, cost less than 3D modeling itself with tools of the type 3DStudio MAX, AutoCAD, Blender, laser scanner, among others. The second is to provide the possibility of achieving great realism since the texturing is done with photographs and, therefore, you get the model directly (using algorithms) from digital photography.

The technique Structure from Motion (SfM) is considered a high-resolution photogrammetric method that is based on the same principles as classical stereoscopic photogrammetry, that is, that the $3 \mathrm{D}$ structure can be solved from an overlay of optical images obtained from different points of view. However, the SfM has its origins in the field of artificial vision and the development of automatic algorithms automatic image correlation (AIC) and the difference fundamentally from conventional photogrammetry as long as the geometry of the scene, the positions of camera, the orientation and deformations of the same are solved by computational calculations. (TomasJover et al., 2016).

On the other hand, in the last decade, initiatives to transform tangible heritage into virtual heritage have increased significantly (Díaz Gómez, 2015; Torres Barragán and Delgado Rojas, 2017). Not only the ability to store large amounts of information, but also the new possibilities for its democratization come into play for the emergence of the concepts of Virtual Heritage and Digital Humanities (Torres Barragán \& Delgado Rojas, 2017).

The concept of Virtual Heritage refers to the tools that allow tangible or intangible goods to be converted into virtual elements in order to preserve them. As for the Digital Humanities, the digital world is not only the adaptation of the humanities to a new era, but is the creation of a new discipline with a more active role in the digital world. In recent years,

\footnotetext{
* Author 1: 1dtaverac@ correo.udistrital.edu.co
} 
numerous institutions such as universities, museums and archives have put themselves at the forefront of the Digital Humanities, finding in these a potential to improve the processes of dissemination of heritage and knowledge in general; demonstrating that the topic of virtual heritage is a current topic (Caro \& Hansen, 2015). According to the above, Virtual Heritage plays a central role in the preservation of the cultural heritage of any nation (Torres Barragán \& Delgado Rojas, 2017) and photogrammetry, including the SfM, remains one of the most used tools to achieve that goal.

This article seeks to contribute, from the academy, to the virtualization of the cultural heritage of the city of Bogota (capital of Colombia) using available technologies and specifically modern digital photogrammetry SfM taking as case study the replica of the sculpture of San Agustín No.28 and the sculpture La Rebeca in order to document the monuments as a mechanism management to ensure their conservation within the cultural heritage of the city and in turn contribute to the program: adopts a monument, developed by Instituto Distrital de Patrimonio Cultural (District Cultural Heritage Institute). (IDPC, 2016).

\section{MATERIALS AND METHODS}

\subsection{Materials}

The taking of photographs and the respective processing of them were carried out with the following materials:

- Camera Canon Esos Rebel T5.

- Smartphone Lenovo K5.

- Digital camera Samsung Techwin CO. LTD Model Digimax A40 /KENOX.

- Desktop Computer (Processor: Intel Core i7, RAM de 16 GB, Sistema operative de 64 Bits)

- Software Pix4D.

- Software Regards 3D.

- Software MeshLab.

\subsection{Study Area}

For this project, two monuments were used in the city of Bogotá (capital of Colombia) described below:

\section{Replica Sculpture of San Agustín No. 28}

The sculpture of "San Agustin No. 28" (Figure 1) is made of concrete and its base is made of rocks; is a replica of a male figure of an Augustinian warrior, it has a height of 2.5 meters, its width is 1.10 meters and has a depth of 0.60 meters, the author of the replica and the year it was made is unknown. The sculpture is located in a green area surrounded by several trees on the avenue the Dorado on 26th Street with ninth road, in the heart of the city; is part of the capital heritage, and is included in the program adopt a monument.

To model this sculpture was used both a Canon Eos Rebel T5 Camera and a Lenovo K5 Smartphone. The data was processed in the Pix4D Software. The photographs of the sculpture were taken around it in a circular form, at a distance of approximately 2 meters, the two capture devices were conventionally located that is the shot was horizontal, but ensuring that the top of the sculpture it will be perceived in the shot plane. With the digital camera, 97 photographs were taken without flash, with a dimension of 5184 pixels wide by 3456 pixels height, with a focal length of $18 \mathrm{~mm}$ exposure time of $1 / 320 \mathrm{~s}$, focal length of
$35 \mathrm{~mm}$. While with the Smartphone they were taken 94 photos without flash wide dimension 3120 pixels per height of 4160 pixels, exposure time $1 / 138 \mathrm{~s}$ and focal length of $4 \mathrm{~mm}$.

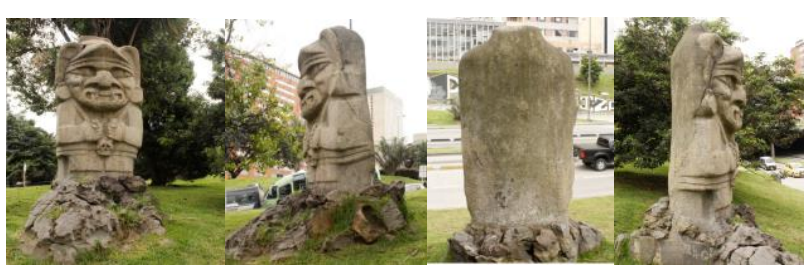

Figure 1. Taking photographs front, side and back of the Sculpture San Agustin No. 28.

\section{Monument "La Rebeca"}

The monument of "La Rebeca" (Figure 2) is documented as part of the first installment of the guide to sculptures and monuments in Public Space of Bogotá (Gobierno de Bogotá, 2008). In this work, the authorship of the work is attributed to Roberto Henao and it is noted that the opening date was July 19 of 1926 , was the first nude to be in the public place with a religious character.

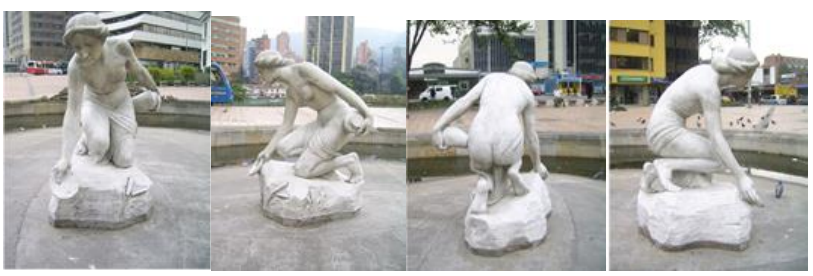

Figure 1. Taking photographs front, side and back of the Sculpture La Rebeca.

For this project, about 120 images were captured with a digital camera SAMSUNG TECHWIN CO. LTD. Model Digimax A40 / KENOX Q1, which has a focal length of $6 \mathrm{~mm}$, an exposure time of $1 / 125 \mathrm{~s}$, each image has a width of 1704 pixels and a height of 2272 pixels. The photos were taken at two distances, the first at a distance of approximately 4 meters making a circular and parallel route to the terrain; and the second to 2 meters, capturing the photos with some inclination to better capture the details of it. Of the total photographs were only used 77 images in the 3D reconstruction, which is done in The Free Software Regard3D. Subsequently, the 3D triangular meshes were processed and edited in MeshLab (open source system).

\subsection{Photogrammetry SfM}

The digital photogrammetry technique of moving structure, or its acronym SfM is considered as an automated methodology that is based on the principles of stereoscopic photogrammetry creating overlap of optical images obtained in different points of view (Tomas-Jover et al, 2016).

However, this technique describes the surface as a numerical structure from a set of points that have been measured from different techniques, the surface is based on a mathematical construction created by surface reconstruction algorithms under calculations of Poisson, Ball Pivoting or the VCG. A particular feature of SFM photogrammetry is that it does not require the camera to be fixed to any base, the operator's intervention during the construction of the model is minimal, the use of 
control points is reduced to the point that some software does not require them (Pereira, 2013).

The software's that have the capability of image processing using SFM digital photogrammetry are highly affordable, there are a large number of free options so this technique has become popular in addition to being a simple and fast technique, However, the licensed software provides among the results a report of the processes that occur internally in the computer.

3D modeling is a tool that has come to play an important role in the generation of cultural heritage in a virtual way, is used by many cities in order to document the goods of cultural interest with which it has made use of the new technologies that have advanced with great speed in recent years, allowing low-cost visual documentation work to be done today. On the other hand, obtaining these 3D models of the elements of cultural interest are of great help to the tourists of the city (Caro, 2012), since it gives them a virtual visit tool in which they can appreciate the monument from different angles, an example of this technique is the application of Google Earth, where you can make visit different world-renowned places.

\subsection{Pix4D Mapper}

Pix $4 \mathrm{D}^{1}$ is the leading professional photogrammetry software, using images into 2D maps and georeferenced and highly accurate 3D models. The photogrammetric system used (Pix4d Mapper), from the images obtained, will identify homologous points in the common areas (overlap) between said images, to then project the points in three dimensions generating the mesh of triangles, which in turn will shape the three-dimensional model (Muniente, 2016).

\subsection{Regards 3D}

Regard3 $\mathrm{D}^{2}$ is a SfM program, which means you can create 3D models from objects using a series of photographs taken of this object from different points of view (Caro, 2015). Regard3d is free software, contains many libraries and third-party programs. They are all published under an open-source license and, as far as I know, are not restricted in their use and are not subject to patents. This means that all work created with Regard3d can be used freely, commercially or not commercially. Regard3d's source code is published under the license MIT Copyright (c) 2015-2018 Roman Heistad.

\subsection{MeshLab}

MeshLab $^{3}$ is an open source system that allows you to process and edit 3D triangular meshes. Provides a set of tools for editing, cleaning, curing, inspecting, rendering, texturing and converting meshes. It offers functions for processing raw data produced by devices / 3D scanning tools and for preparing models for 3D printing (Cignoni et al., 2008).

\subsection{Workflow}

As far as the Replica de San Agustín was concerned, the workflow was automatic, following the stages proposed in the Pix 4d software (Figure 3). The first step determines the settings of the taking of the photographs, calculating the actual location

\footnotetext{
${ }^{1}$ https://www.pix4d.com/

2 http://www.meshlab.net/

${ }^{3}$ http://www.regard3d.org/index.php
}

and parameters of the original images, through Advanced Automatic Air Triangulation and package block adjustment, key points are defined in at least three images and a reconstruction of the object is done into a mesh of dots. In both cases, the software fully acknowledged the images used to rebuild the model. In the second step, densify the points from the matches generated between images, this process is carried out and the three-dimensional model is generated.

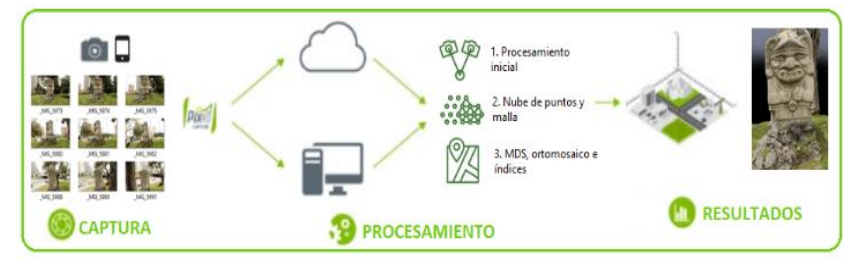

Figure 2. Sculpture San Agustín No.28 workflow.

The methodology used for the realization of the 3D model of this sculpture is based on the taking of photographs, which are then filtered and processed in the Pix $4 \mathrm{~d}$ photogrammetric software as illustrated below in Figure 4:

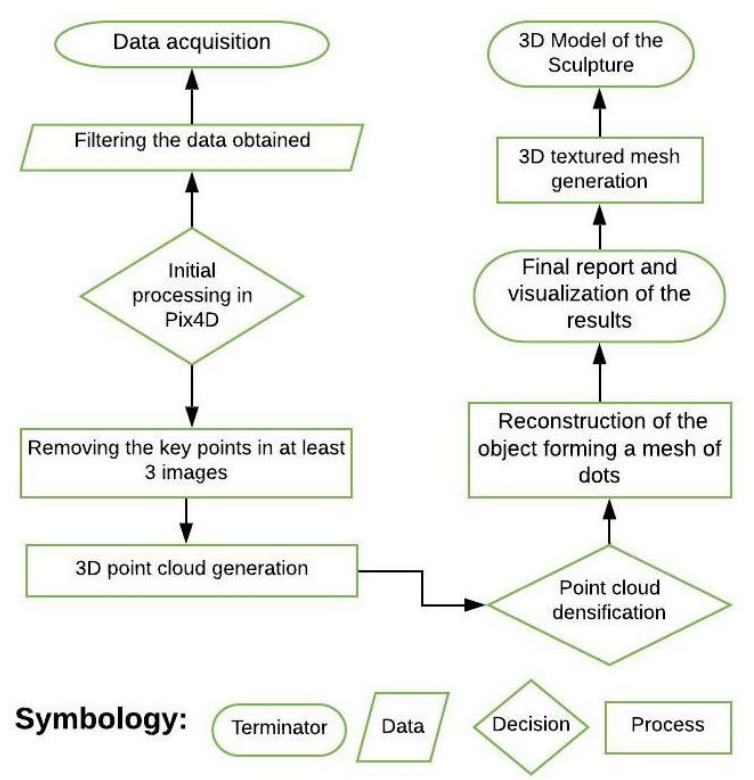

Figure 3. Methodology used for the 3D Model of the Replica Sculpture San Agustín No.28.

As for the sculpture of La Rebeca, the workflow (Figure 5) begins in the program Regards 3D, which generates a grid from matrices of points in common between a couple of images, which, using mathematical processes, are triangulated and subsequently densified under calculation parameters such as those of Poisson (using the Matches option). Triangulation is then selected using the SFM technique. The densification process joins the points found using the CMVS method (Clustering Views for Multi-view Stereo). This densification was exported in a .mlp format to the MeshLab software, where the background points were removed. 


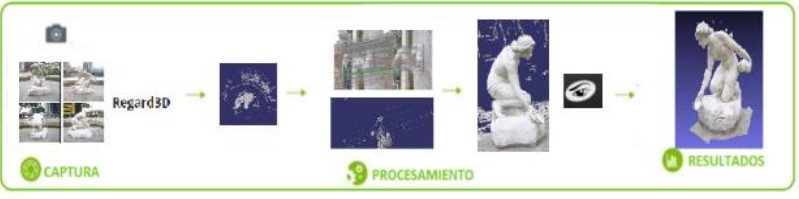

Figure 4. La Rebeca monument workflow.

Figure 6 shows the general methodology that was implemented in the 3D modeling of the sculpture La Rebeca.

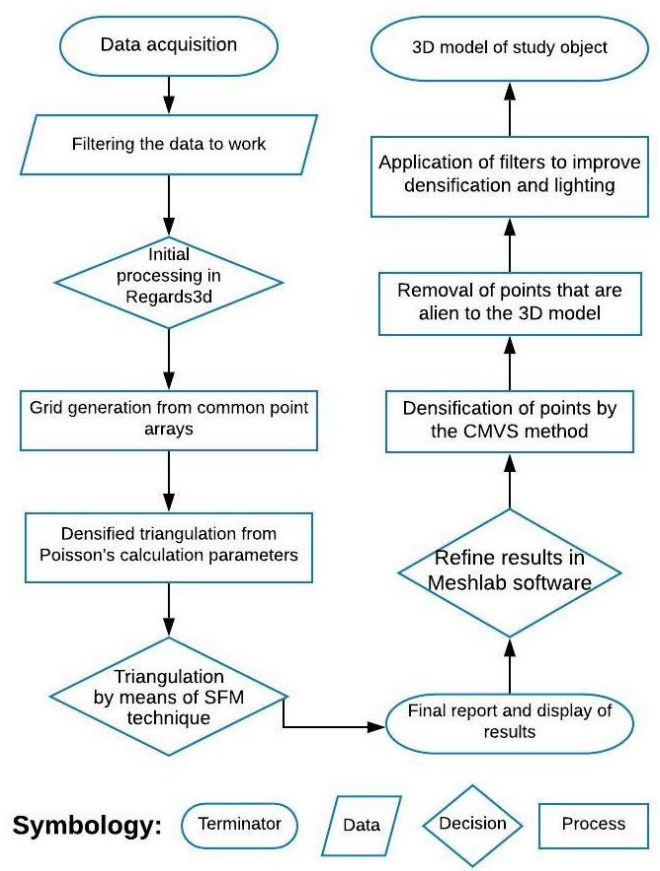

Figure 5. Methodology used for the 3D model of the La Rebeca Monument.

\section{RESULTS}

The results are presented separately for each monument.

\subsection{Replica sculpture of San Agustín No. 28}

The first process performed in the software visualizes a graphical interface in which is the model and an approximation of the location in the taking of the photographs, when the resolution of the images is higher this allows more key points to be identified. Also, the software's report shows a graph of the ellipses of uncertainty, which tell us the size and direction of the error, that is, they describe how one image is placed relative to the other by means of link points.

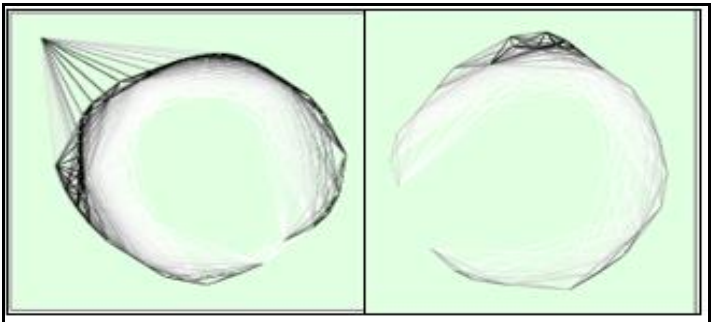

Figure 7. Ellipse of uncertainty canon camera(left), Lenovo camera (right).

Figure 7 shows the uncertainty ellipses of the cameras, where the lines between each image represent the coincidences between key points, black tones represent a greater number of coincidence and white tones represent a smaller number of coincidences.

\section{Camera Canon Eos Rebel T5}

A first test was performed where the captured images were 97 and all were used in the software, the results obtained were not optimal (Figure 8), according to the report generated by the software in the majority of the images were not found many points in common, that is the overlap of images was deficient which generated white spaces which are not reconstructed, in addition to redundancy in the images that generate noise in the final product when reconstructing.
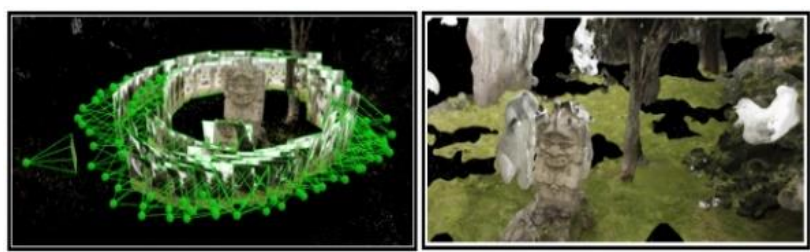

Figure 8. Position of the photographs (left), result of the generation of the 3D model (right).

Test two: To perform this modeling (Figure 9), 41 images were used, which were processed in a time of 20 minutes with 9 seconds, resulting in 461468 observation points for the 2D block setting, a 179247 number for the 3D block setting and an error per pixel of 0.177889 .

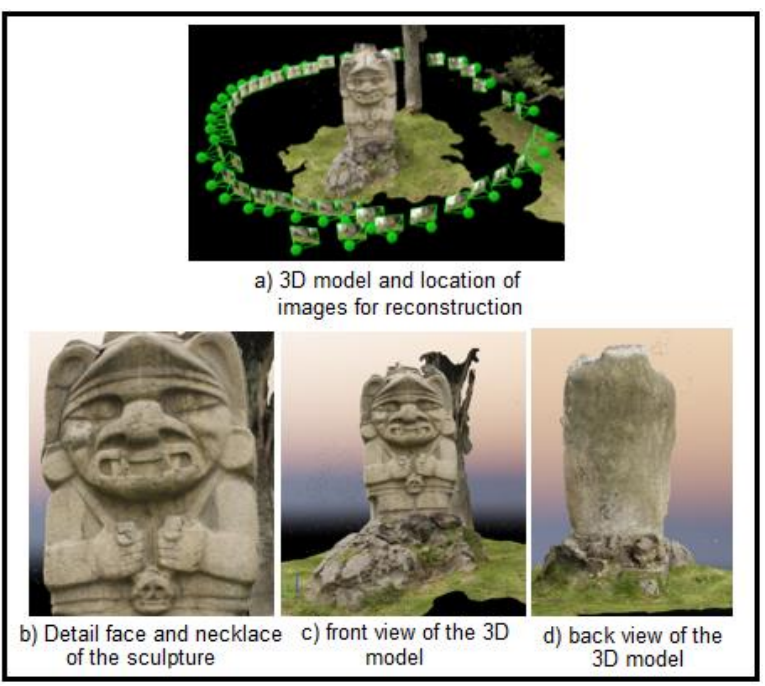

Figure 6. 3D Model replica sculpture San Agustín No 28. 


\section{Smartphone Lenovo K5}

A first test was carried out (Figure 10) where the 94 photographs were entered in the software, the results obtained were not optimal since the reconstruction is not the expected one, it is therefore decided to conduct a second test using fewer photographs to avoid data redundancy.
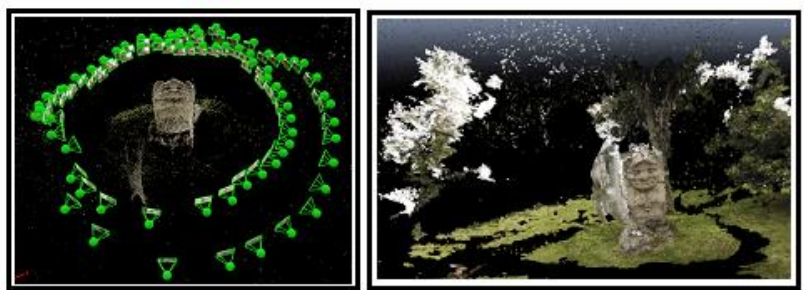

Figure 10. Position of the photographs (left), result of the generation of the 3D model (right).

Test two: For this case only 31 images were used (Figure 11) which took 19 minutes with 5 seconds resulting in 181585 observation points for the 2D block setting, a 73720 number for the 3D block setting and an error per pixel of 0.156236 .

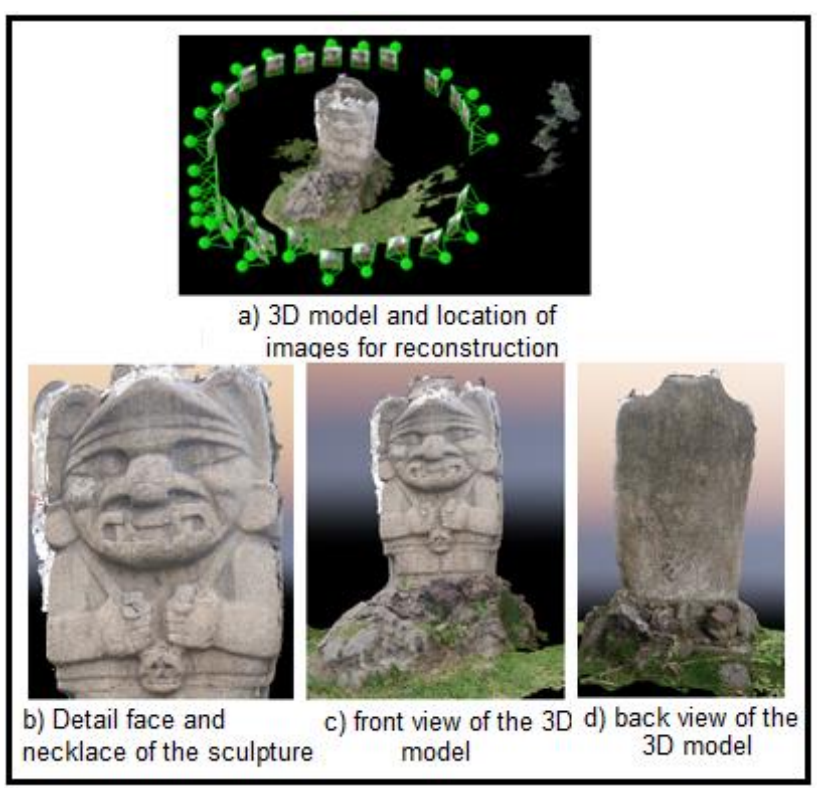

Figure 11. Three-dimensional model sculpture San Agustín No.28.

\subsection{Monument "La Rebeca"}

In order to model the sculpture 77 images were used in the 3D reconstruction, which is done in the free software Regard3d, Figure 12 shows the location of these photographs.

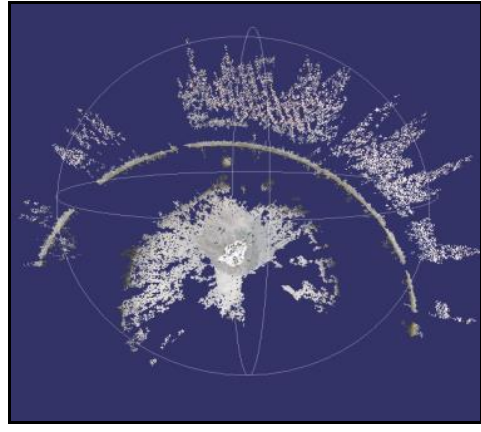

Figure 12. Tour of the photographs for the documentation of La Rebeca, nadir view.

For the generation of three-dimensional models, the images are entered into the software, which automatically detects the camera with which the images and the properties of each image were captured. In the program a grid of is generated from matrices of common points between a pair of images, which using mathematical processes are created triangulation that are later densified under calculation parameters such as those of Poisson (uses the Matches option). This process shows how many common points a pair has (Figure 13), and lasts 20:01 minutes.

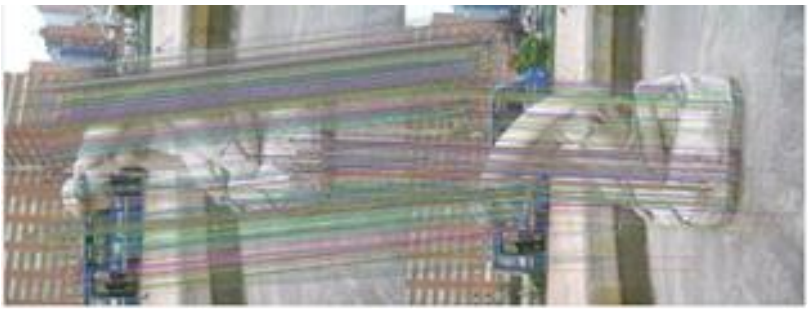

Figure 13. Common points among the images.

In the triangulation there are 74 of 77 cameras with a number of 12973 points in a time of 02:46 minutes. In this process triangulation is selected using the SFM technique (Figure 14).

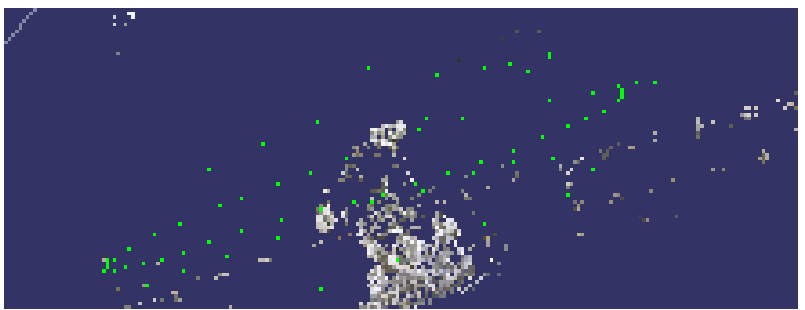

Figure 14. Results of Triangulation.

In the densification process, the points found by the CMVS (Clustering Views for Multi-view Stereo) method are combined, as illustrated in Figure 15. This one lasts 26:33 minutes.

\footnotetext{
${ }^{4}$ https://www.di.ens.fr/cmvs/
} 


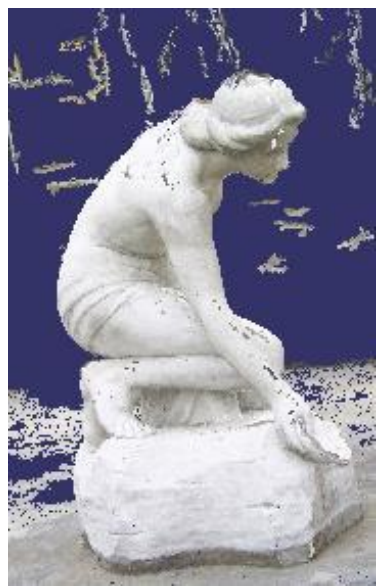

Figure 15. Results of point densification.

\section{Virtualization of La Rebeca - MeshLab}

In order to create a much more refined model, the dot densification created in Regards 3D (Figure 15) is exported in a *.mlp format to the MeshLab software. In this software points that do not belong to the model of the monument are removed (using the option to select vertices and then remove vertices). This allows the modelling of La Rebeca (Figure 16). In addition to the off-model point removal option, this tool provides a variety of filters that are applied to improve spot densification, lighting, and reconstruction resolution.

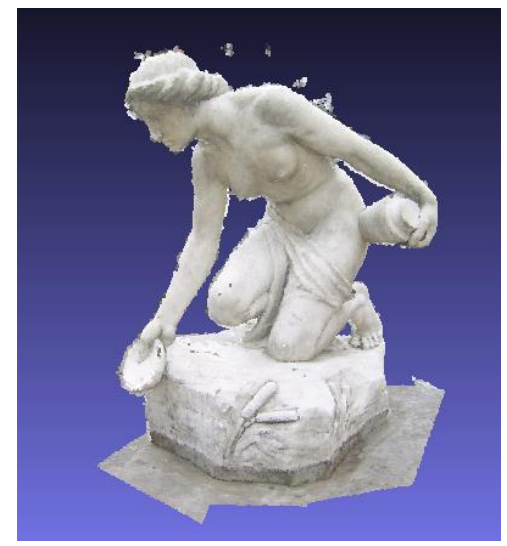

Figure 16.3D modeling of The Rebeca.

\section{DISCUSSION}

With the results obtained with respect to the Replica Sculpture of San Agustín No. 28 it is evidenced that the reconstruction was successful in both cases, and the workflow adopted was adequate to meet the proposed objective, because with the devices used it was possible to make the 3D modeling of the sculpture with a good level of detail.

If we compare the quality of detail between the two cameras it is evident that with the canon camera Eos Rebel T5 (Figure 9) has a better detail in the quality of the images, However, more photos were needed for reconstruction than those used with the Lenovo cell phone camera (Figure 11).

The top of the sculpture (Figure 16) is not fully reconstructed because no photographs were taken from this perspective in both cases, evidencing lack of information being this more notorious in the smartphone camera, however, despite not having all the prospects, the result obtained offers a model with sufficient volume.

It is also evident that when taking photographs with a smartphone of medium range is achieved very good results of high quality making it possible to save costs and time at the time of work in the field, which allows the virtualization of cultural heritages, so it is pertinent to establish requirements to homogenize this process to different monuments.
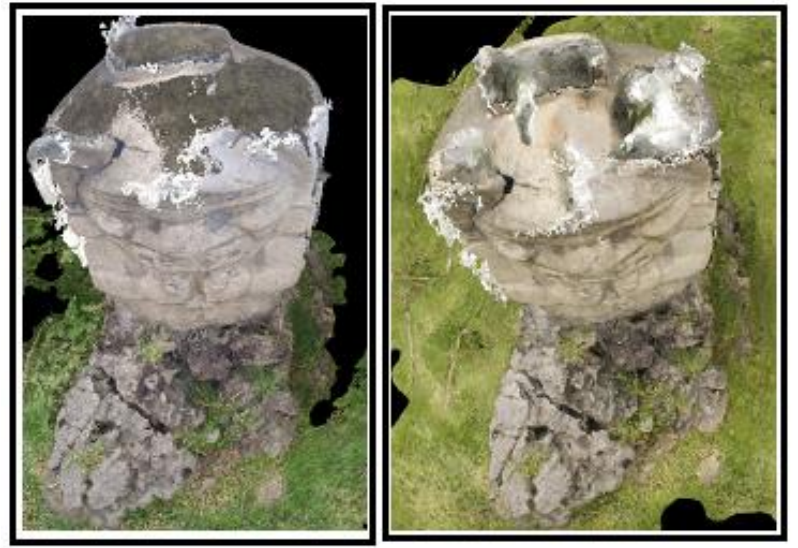

Figure 17. Error Top Object, 3D Model Lenovo Smartphone (Left) Model 3D Canon Camera (Right).

As for the Monument "La Rebeca", the way in which the images are captured is of utmost importance, since the theory available holds that SFM photogrammetry does not take into account the way in which the images are taken (Rodríguez Miranda et al., 2015), in practice images that had been taken vertically were not accepted by the software.

This would be in line with what was presented in the work of Lopez-Manchero Bendicho (Lopez-Manchero Bendicho et al., 2017). In addition to important factors such as the lighting of the scene play a fundamental role as, when facing a white object, the sunlight affects the shot and this makes the system not easily find the points in common between the images because it is presented over exposure and certain areas disappear forming a white spot (Figure 17).

In this case, the quality and resolution of the detail of the model generated in order to have a virtual record of the cultural heritage of the city is not expected, since the model is not generated for the entire surface, spaces without information and at the moment an approach is made, information is lost, similar to what they report in the work of Colomo and his team (Colomo et al., 2016), which indicates that it is necessary to have more photographs of these sites, mainly the top of the monument, which because of the way it was taken was not recorded. However, in areas where there are multiple points of view of the same point of view, reconstruction allows to arrive at details that outline the potential of digital photogrammetry in the virtualization of cultural heritage. 


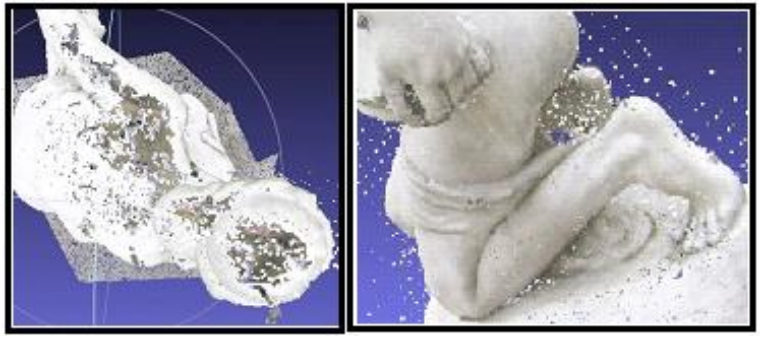

Figure 18. Top view of the Monument- Undeveloped Areas (Left), Details hands and feet of the monument (Right).

In initiatives to virtualize heritage (tangible and intangible) there are several projects that use digital photogrammetry, such as the work of Lopez-Menchero Bendicho and his team (2017), they use digital night photography and photogrammetry for the documentation of Petroglyphs, which like monuments located in public space when outdoors can deteriorate and be lost. In this project the documentation of the engravings was done with a reflex camera mounted on a tripod, and the photogrammetric process was carried out in the software Agisoft, the models obtained were later exported to work in the MeshLab software, for the application of filters and enhancements.

For their part, Ma'arof and his team (2013) used short-range photogrammetry to model and document historical monuments in Malaysia based on Malaysian regulations (Act 645 of 2005 of National Heritage Regulations), thus allowing future visitors to have virtual tour experiences in some parts of the museum, such as the Aladin Palace, the Gallery and the temple. For this they used a Nikon SLR DSO camera and a tripod that they located at distances between 2 and 4 meters and leaned on ground control points with known coordinates and used the Photo modeler scanner software.

Other applications of photogrammetry have allowed the digitalization of biological structures in three dimensions, more specifically skeletons of extinct reptiles exhibited in museums (Fau et al., 2016), in this case at the Museum of Natural History in Paris, supporting the virtualization and quantitative analysis of large specimens. In this case a SLR camera was used, more than 2500 photographs were taken and 3D models were reconstructed in the Agisoft (proprietary) and Virtual SfM (free) software.

More recently in 2018 (Gudiño Maussan et al., 2018), used ground photogrammetry, to support more than 11800 captured with different low-cost cameras, and using Virtual SFM software, MeshLab, Cloud compare and Parkview reconstruct 3D models in order to identify dinosaur footprints (ignites) in a geological unit in Mexico.

Finally, Diaz Gómez and his team (2015) argue that, through the use of virtual content, cultural heritage can take a step forward and embark on an equal footing in the new era of Tecnología de la Información y la Comunicación (TIC's) (Information and Communication Technology). Greater and better dissemination and marketing can be achieved with 3D virtual content. The fact that it can be linked to a web page also makes it possible to achieve greater dissemination among new generations, more likely to acquire information through this channel.

In terms of innovation, this article proposes two methodologies for 3D modelling of monuments and sculptures that allow the virtualization of cultural heritage using a multidisciplinary tool, in addition to demonstrating that with different low-cost devices, results can be achieved with excellent quality, in both cases it was possible to structure recommendations that allow the process to be homogenized, so that it can be applied to other monuments so that they can be virtually preserved with lowcost inputs and little dependent operator, In addition, the technique used and the different workflows that were implemented demonstrate that they are efficient and very feasible to be applied since most of the process is performed automatically.

On the other hand, according to the experience gained and in accordance with some guidelines given by Micheletti and his team (Micheletti, et al.,2014), it is recommended that when taking the photographs, one takes into account:

1. Plan the data capture methodology taking into account the camera and the scale to be worked.

2. Ensure coverage of the scene, taking into account that each point must appear in at least three images and must be captured from different positions.

3. The scene should be static and the lighting should be consistent, avoiding underexposed or overexposed and blurred images.

As for the processes carried out for a three-dimensional texturized model from the SFM technique were given automatically the user should only indicate the type of reconstruction he wants and the triangulation to use. In this sense, the results obtained are favorable, since, with low-cost solutions, using non-metric cameras and free software, a virtualization of heritage can be achieved (Torres Barragán \& Delgado Rojas, 2017), to assist the District's cultural heritage documentation initiatives (Bogota Government, 2008).

In case this initiative is taken by the District, it is possible that the taking of photographs can be done with a certain type of isolation and preparation of the monument (Gudiño Maussan et al., 2018; Fau et al., 2016) that can reduce the errors found in this project, allowing to fully achieve the objective of the virtualization of cultural heritage at low cost.

\section{CONCLUSIONS}

This project used two emblematic monuments located in the heart of the city of Bogota to make an application of SfM photogrammetry with the aim of performing the $3 \mathrm{D}$ reconstruction texturized as a contribution to the virtualization of the cultural heritage of the city and as a tool for its conservation, from the use of different devices of low cost and easy access, in order that this, serves as a contribution from the academy for the program: Adopts a monument. The objective set was achieved, as shown throughout this work the final products obtained meet the initial expectation of threedimensional reconstruction and establish a workflow to be applied to other monuments in this city or another.

The methodologies proposed throughout this work serve as a reference to establish the basic requirements to standardize the process so that it is subsequently applied to different monuments, so that they can be virtually preserved with lowcost inputs and little dependent operator. The results are promising for the preservation of the city's cultural heritage so that they are known to future generations and allow for a greater impact of the program: Adopt a Monument. 


\section{REFERENCES}

Caro José L., (2012). Fotogrametría y modelado 3D: un caso práctico para la difusión del patrimonio y su promoción turística. IX Congreso Tecnologías de la Información y las Comunicaciones (TuriTec'2012) - Málaga, 25 y 26 de octubre de 2012 - ISBN 978-84-615-9946-2. Universidad de Málaga, page 2.

Caro J., Salvador H., (2015). De la fotogrametría a la difusión del patrimonio arqueológico mediante game engines: Menga un caso de estudio. Virtual Archaelogy Review, page 58-68.

Cignoni P., Callieri M., Corsini M., Dellepiane M., Ganovelli F., Ranzuglia G., 2008 MeshLab: an Open-Source Mesh Processing Tool, Sixth Eurographics Italian Chapter Conference, page 129-136.

Colomo, C.; Pérez, JL.; Gómez, JM.; Rosales, FJ (2016) Metodología y Aplicación práctica para la digitalización de Patrimonio Cofrade Mediante la Fusión de Datos de Laser Escáner y Fotogramétricos. Arqueología 2.0, 110-117.

Díaz Gómez F., Jiménez J., Barreda Benavent A., Asensi Recuenco B., Hervás J. (2015). Modelado 3D para la generación de patrimonio virtual. Virtual Archaelogy Review, 29-37.

Fau M., Cornette R., Houssaye A., 2016, Photogrammetry for 3D digitizing bones of mounted skeletons: potential and limits. Comptes Rendus Palevol.

http://dx.doi.org/1o.1016/j.crpv.2016.08.003

Gobierno de Bogotá (2008), Bogotá un museo a cielo abierto: Guía de esculturas y monumentos conmemorativos en el espacio público. Vol. 1. Talleres bogotanos de Panamericana. $418 \mathrm{p}$.

Gudiño Maussán J, Aguilar F., Hernández-Rivera R,2018: Aplicación de fotogrametría digital para el registro de las huellas de dinosaurio de la Formación Cerro del Pueblo (Campaniano tardío), Coahuila, México. Boletín de la Sociedad Geológica Mexicana, VOL. 70, NO. 2. pp. 307-324.

IDIPRON. (13 de agosto de 2018). El IDIPRON adopta el monumento de La Rebeca. Obtenido de $\mathrm{http}: / / \mathrm{www}$.idipron.gov.co/idipron-adopta-un-monumento

Instituto Distrital de Patrimonio Cultural. (12 de agosto de 2018). Vive la primera 'adoptatón' de monumentos: gran regalo en los 480 años de Bogotá. Obtenido de http://idpc.gov.co/primera-adoptaton-de-monumentos/

Instituto Distrital de Patrimonio Cultural. (s.f.) 2016. Programa adopta un monumento. Obtenido de http://idpc.gov.co/monumentos-en-espacios-publicos/

López-Menchero Bendicho V., Marchante Ortega A., Vincent M. Cardenas A., Martín-Buitrago J., Onrubia Pintado J., 2017: Uso combinado de la fotografía digital nocturna y de la fotogrametría en los procesos de documentación de petroglifos: El caso De Alcázar De San Juan (Ciudad Real, España), Virtual Archaelogy Review, 8(17) 64-74.

Ma'arof I., Zubaidah Bahari S., Abd Latif Z., Aishah Sulaiman N., Manan Samad A., 2013, Image based modeling and documentation of Malaysian historical monuments using Digital
Close-Range Photogrammetry (DCRP), 2013 IEEE International Conference on Control System, Computing and Engineering, 29 Nov.-1 Dec.

Micheletti, N., Chandler, J. H., \& Lane, S. N. 2014: Investigating the geomorphological potential of freely available and accesible Structure-fromMotion photogrammetry using a smartphone. http://dx.doi.org/10.1002/esp.3648.

Rodríguez Miranda Á., Vidiella P.P., Lazaro R., Melo J. ,2015: Reutilización de pares fotogramétricos de elementos arquitectónicos para la obtención de modelos 3D y orto fotografías a partir de técnicas SFM. Arqueología de la Arquitectura, $12 . \quad$ Doi: http://dx.doi.org/10.3938/arq.arqt.2015.004

Tomás-Jover R., Riquelme Guill A., Cano González M., Abellán Fernández A., Jordá L., 2016: Structure from Motion (SfM) una técnica fotogramétrica de bajo coste para la caracterización y monitoreo de macizos rocosos. Sociedad Española de Mecánica de Rocas, 209-216.

Torres Barragán, C., \& Delgado Rojas, C. (2017). Patrimonio virtual y humanidades digitales: Debates y Puntos de Encuentro. Boletín OPCA12: Monumentos y esculturas en el espacio público. La construcción de signos compartidos, 52.

UNESCO, 2013, Managing Cultural World Heritage (16/11/2013) () UNESCO / World Heritage Centre / Image Source: https://whc.unesco.org/document/125839.

UNESCO. 2017: Indicadores centrales Sostenibilidad del patrimonio. Consultado junio 2018, Disponible en: https://es.unesco.org/creativity/sites/creativity/files/digitallibrary/cdis/Patrimonio.pdf. 